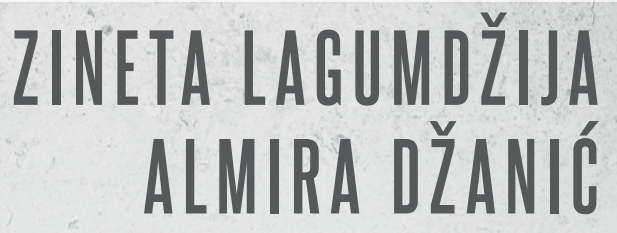

Pedagoški fakultet Univerziteta u Bihaću zineta.lagumdzija@gmail.com dzanic_almira@hotmail.com

\title{
REFLEKSIVNI GLAGOLI I NJIHOVA LEKSIKALIZACIJA U ODABRANIM RJECNICIMA BOSANSKOG JEZIKA
}

Sažetak: Paralelno s promjenama u izvanjezičkoj stvarnosti razvijaju se i nova sredstva komunikacije. U jeziku kao sredstvu komunikacije nastaju nove jezičke strukture i novi modeli opisa jezičkih struktura. Jedan od jezičkih fenomena koji je naišao na veliki interes u njemačkoj lingvistici su refleksivni glagoli. Njihovo nastajanje pokazalo se kao otvoren proces i odraz kreativne upotrebe jezika. Uvid u različite tekstne vrste i rječnike bosanskog jezika pokazuje da su refleksivni glagoli veoma česti i u bosanskom jeziku. U bosanskoj lingvistici ove strukture nisu naišle na interes kakav zaslužuju. Cilj ovog rada je dati osvrt na procese nastajanja refleksivnih glagola i njihovu leksikalizaciju u odabranim rječnicima bosanskog jezika uz primjenu jednog od modela opisa refleksivnih glagola u njemačkoj lingvistici.

Ključne riječi: refleksivni glagoli, refleksivizacija, leksikalizacija, rječnici bosanskog jezika.

\section{Uvod}

U njemačkoj lingvistici kategorija refleksivnosti već se nekoliko decenija intenzivno istražuje, a nova saznanja ulaze i u nova izdanja gramatika njemačkog jezika. U bosanskoj lingvistici informacije o kategoriji refleksivnosti ostale su na nivou Gramatike bosanskog jezika za srednje škole koja je Nakladom Zemaljske vlade za Bosnu 


\section{KNJIŽEVNI JEZIK 29, 2018. (139-158]}

i Hercegovinu štampana u Zemaljskoj štampariji u Sarajevu 1890. Nepoznavanje kretanja u savremenoj lingvistici izvan granica Bosne i Hercegovine neminovno dovodi do negativne interferencije kod učenja stranih jezika, što ukazuje na potrebu kontrastivnih istraživanja pojedinih jezičkih fenomena u svrhu usklađivanja opisa bosanskog jezika s tendencijama u savremenoj lingvistici na evropskom pa i svjetskom nivou. Njemački lingvista Stefanowitsch (2008: 151f.) smatra da se u novijim istraživanjima sve više potvrđuje da kombinacija metoda korpusne lingvistike i moderne gramatičke teorije daje najbolje rezultate kod opisa pojedinih jezičkih fenomena. Detaljna analiza jezika kao sistema prema Stefanowitschu (2008: 152) ima za posljedicu površnu analizu pojedinih konstrukcija te, stoga, najčešće samo preuzima dosadašnje rezultate, što krije opasnost da se previdi kompleksnost pojedinih jezičkih struktura. Kvantitativne i kvalitativne metode korpusne lingvistike daju mogućnost za detaljan opis formalnih, semantičkih i pragmatičkih osobina pojedinih jezičnih struktura. Ovaj je autor mišljenja da tek iz detaljne analize pojedinih jezičkih fenomena treba, korak po korak, izvoditi karakteristike jezika kao sistema. Metode korpusne lingvistike nisu ni u kojem slučaju zamjena za lingvističku argumentaciju koja je svrha gramatičke teorije. Metode korpusne lingvistike samo pružaju mogućnost odabira najboljeg materijala, koji će u okviru gramatike biti podvrgnut lingvističkoj interpretaciji. Saradnja korpusne lingvistike i gramatičkih teorija plodonosna je i u obrnutom smjeru. Za korpusnu je lingvistiku također od velikog značaja da od gramatičkih teorija dobije jasno definiranu jedinicu za analizu na koju će biti primijenjene metode kojima raspolaže.

Uvid u gramatike bosanskog jezika potvrđuje da svaka nova gramatika u velikoj mjeri preuzima opis i primjere upotrebe pojedinih jezičkih struktura iz prethodnih izdanja, koji su uz to često i pogrešni, na što ukazuje i Riđanović (2003: 65) u prikazu Gramatike bosanskog jezika (Jahić et al. 2000). Nova istraživanja u lingvistici bosanskog jezika su ili nedostatna ili završe u časopisima koji nisu dostupni širem krugu korisnika, te samim tim ne služe namjeravanoj svrsi. 
U sljedećim poglavljima dat ćemo osvrt na prikaz kategorije refleksivnosti u odabranim gramatikama njemačkog i bosanskog jezika, a potom ćemo, uz primjenu jednog od modela opisa nastajanja leksički refleksivnih glagola u njemačkom jeziku, kroz korpusno istraživanje odabranih rječnika bosanskog jezika pokušati dokazati odvijanje istog procesa u bosanskom jeziku.

\section{Teoretski okvir}

\subsection{Kategorija refleksivnosti u njemačkom jeziku}

Po autorima najnovije Dudenove gramatike Duden 4 (2006: 279) refleksivna zamjenica u njemačkom jeziku poznaje samo jednu jednoznačnu formu, i to sich, koja se upotrebljava u 3. licu jednine i množine. Ona ne poznaje razlike u broju i rodu i može biti upotrijebljena samo u dativu i akuzativu: (...) Ostali oblici odgovaraju oblicima lične zamjenice.

Najjasniji prikaz kategorije refleksivnosti kao glagolske kategorije u njemačkom jeziku predstavlja morfosintaksička klasifikacija refleksivnih oblika autora Helbiga i Busche, koja je i najčešće citirana klasifikacija sistema refleksivnih oblika u njemačkom jeziku (up. Lagumdžija 2018: 20ff). Za sveukupnost veze glagola i refleksivne zamjenice autori Helbig i Buscha upotrebljavaju termin reflexive Verben im weiteren Sinne (refleksivni glagoli u širem smislu). Sa sintaksičkog aspekta, a uvažavajući i druge specifičnosti veze glagola i refleksivne zamjenice, Helbig i Buscha (up. Buscha 1982; Helbig - Buscha 2001; Helbig 2004) razlikuju četiri tipa refleksivnih glagola u širem smislu:

1. Reflexive Konstruktionen (refleksivne konstrukcije), ${ }^{1}$

2. Reflexive Verben im engeren Sinne (refleksivni glagoli $\mathrm{u}$ užem smislu),

Pod pojmom "refleksivne konstrukcije" Helbig - Buscha podrazumijevaju refleksivno upotrijebljene prijelazne glagole kod kojih je refleksivna zamjenica posebna vrsta objekta $\mathrm{u}$ dativu ili akuzativu. 


\section{KNJIŽEVNI JEZIK 29, 2018. (139-158]}

3. Reflexive Konstruktionen und reflexive Verben mit reziproker Bedeutung (refleksivne konstrukcije i refleksivni glagoli $s$ recipročnim značenjem) $\mathrm{i}$

4. Reflexive Formen (refleksivni oblici).

Kod refleksivnih konstrukcija radi se o istoj logičkoj relaciji agens - pacijens (vršitelj - trpitelj) kakva postoji kod prijelaznih glagola. Refleksivna je zamjenica kod refleksivnih konstrukcija posebna vrsta objekta, referencijalno identičnog sa subjektom, te se ovdje radi o semantičkoj refleksivnosti / povratnosti kao specijalnom obliku prijelaznosti (tranzitivnosti). Postupak supstitucije pokazuje da je kod ovih glagola povratnu zamjenicu moguće zamijeniti imenicom ili drugom zamjenicom (2), te ih dovesti u odnos koordinacije (3):

1) Die Frau wäscht sich. (Žena se umiva),

2) Die Frau wäscht das Kind. (Žena umiva dijete) i

3) Die Frau wäscht sich und das Kind. (Žena umiva sebe i dijete).

Kod "refleksivnih glagola u užem smislu" (reflexive Verben im engeren Sinne) refleksivna zamjenica je, za razliku od refleksivnih konstrukcija i refleksivnih formi, dio glagolskog leksema, koji se kao takav unosi u leksikon i predstavlja svojevrsni tvorbeni tip neprijelaznih glagola. Proba supstitucije kod "refleksivnih glagola u užem smislu" je negativna (up. Helbig - Buscha 1998: 209):

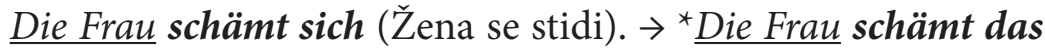
Kind (Žena stidi dijete).

Postojanje glagolskih konstrukcija koje su u odnosu sinonimije prema refleksivnim glagolima u užem smislu također potvrđuje tezu da je kod ovih glagola refleksivna zamjenica sastavni dio glagola (up. Buscha 1982: 171), npr.:

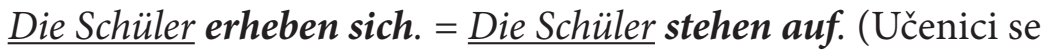
podižu. $=$ Učenici ustaju). 
Refleksivni glagoli u užem smislu nisu jedinstvena grupa glagola u pogledu postojanja nerefleksivne varijante, što će biti i predmet istraživanja na korpusu glagola iz odabranih rječnika bosanskog jezika.

U određenim refleksivnim konstrukcijama, kao i kod različitih refleksivnih glagola u užem smislu, uz glagol i refleksivnu zamjenicu pojavljuju se najmanje dva subjekta, a refleksivna zamjenica ne izražava odnos povratnosti i identiteta u izravnom smislu, već odnos uzajamnog djelovanja. Ove refleksivne konstrukcije u množini su homonimne, što znači da ovisno o kontekstu mogu izražavati povratnost radnje na subjekt ili, pak, odnos reciprociteta, tj. uzajamnog djelovanja više subjekata. Tako npr. rečenica Hans und Peter waschen sich (Hans i Petar se umivaju) može da znači:

1) $\rightarrow$ Hans wäscht sich, und Peter wäscht sich. (Hans se / sebe umiva i Petar se / sebe umiva.) $\rightarrow$ povratni odnos, identičnost subjekta i objekta;

2) $\rightarrow \underline{\text { Hans }}$ wäscht Peter, und $\underline{\text { Peter }}$ wäscht Hans. $=\underline{\text { Hans und }}$

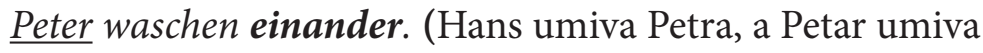
Hansa. $=$ Hans i Petar umivaju jedan drugoga.) $\rightarrow$ odnos uzajamnog djelovanja / reciprociteta.

Postoji, međutim, i manja grupa glagola koji su u svom osnovnom značenju recipročni. Kao i kod refleksivnih konstrukcija s recipročnim značenjem, ovi se glagoli obično pojavljuju u množini, ali mogu stajati i u jednini, pri čemu se drugi subjekt obavezno povezuje prijedlogom mit (sa / s), npr. glagol sich verbrüdern (bratimiti se).

Hans und Peter verbrüdern sich (miteinander). (Hans i Petar bratime se (jedan s drugim).) $\rightarrow$ Hans verbrüdert sich mit Peter. (Hans se bratimi s Petrom.)

Četvrti tip u klasifikaciji "refleksivnih glagola", kako autori Helbig i Buscha nazivaju sveukupnost upotrebe refleksivne zamjenice uz glagole, predstavljaju Reflexive Formen (refleksivni oblici). Pod pojmom "refleksivni oblici" Helbig i Buscha podrazumijevaju Medio-Passiv (medijalni pasiv) i Reflexiv-Passiv (refleksivni pasiv). 


\section{KNJIŽEVNI JEZIK 29, 2018. (139-158]}

Osnovni neobilježeni glagolski oblici koji se unose u leksikon aktivni su, nerefleksivni i prelazni glagolski oblici. U tom smislu Welke (1997: 225), objašnjavajući navedene termine autora Helbig i Buscha, smatra da - na isti način kako pojedini glagoli imaju aktiv i pasiv kao oblike konjugacije - i refleksivni oblici predstavljaju posebne oblike konjugacije pojedinih, inače nerefleksivnih glagola. Kao tipične primjere refleksivnih oblika Helbig i Buscha navode primjere medijalnog pasiva kakve predstavljaju sljedeći primjeri (Helbig - Buscha 1998: 219-220):

Der Schlüssel wird sich finden. (Ključ će se naći),

Der Apfel schält sich schlecht. (Ova jabuka se teško guli) i

In der neuen Bibliothek arbeitet es sich gut. (U novoj biblioteci se može dobro raditi).

Refleksivni pasiv poseban je oblik bezličnog pasiva (up. Buscha 1982; Hundt 2002; Helbig 2004). Refleksivni pasiv karakterizira istovremeno prisustvo sich kao refleksivnog markera i pasivnog oblika u njemačkom jeziku (werden + Partizip II):

Es wurde sich heftig geschlagen. (Žestoko se tuklo) i

Hier wird sich amüsiert. (Ovdje se zabavlja).

Refleksivni pasiv jednog broja refleksivnih glagola čuje se češće u govornome jeziku, a vrlo rijetko susretne u literarnim djelima, te je zapravo izuzetak od pravila. I dok je gramatičnost medijalnog pasiva neupitna, o gramatičnosti refleksivnog pasiva lingvisti još nemaju jedinstven stav. Stoga refleksivni pasiv još ne nalazimo u njemačkim gramatikama.

\subsubsection{Pravci razvoja refleksivnih glagola u njemačkom jeziku}

Aktiv, nerefleksivna i prijelazna forma glagola primarne su karakteristike glagola kao leksikonske jedinice (up. Welke 1997: 225). Svi ostali oblici glagola nastaju kasnije kao rezultat potrebe za prikazivanjem izvanjezičkih sadržaja iz različitih perspektiva. U skladu s principima ekonomičnosti jezika nove forme ne nastaju "ni iz čega", već 
nastaju ili prema tvorbenim modelima postojećih struktura ili kao kombinacija već etabliranih jezičkih struktura.

Prema navedenoj Welkeovoj konstataciji sve su refleksivne forme "sekundarne forme" glagola kao leksikonske jedinice. Refleksivni glagoli u užem smislu, tj. glagoli kod kojih je sich dio glagolskog leksema, nisu jedinstvena grupa glagola u pogledu postojanja nerefleksivne varijante. U okviru ove grupe glagola razlikuju se glagoli koji postoje samo u refleksivnoj formi (reflexiva tantum), refleksivne varijante nerefleksivnih glagola $s$ promjenama značenja različitog stupnja, te refleksivni glagoli s fakultativnom upotrebom refleksivne zamjenice, koja može biti izostavljena bez promjene značenja. Ova posljednja grupa refleksivnih glagola relativno je malobrojna. U svrhu preciziranja terminologije Welke (2005) dijeli refleksivne glagole na inherentno refleksivne glagole (IRG) i medijalno refleksivne glagole (MRG), a ukazuje i na slučajeve refleksivizacije neprijelaznih glagola koja izlazi iz okvira regularne gramatike. Kriterij za ovu podjelu je postojanje nerefleksivnog glagola $\mathrm{u}$ istom obliku s manjim ili većim razlikama u značenju.

IRG, u gramatikama poznati kao reflexiva tantum, jesu glagoli koji su primarno refleksivni, što znači da nemaju svoj nerefleksivni pandan, već su u svom prvom registriranju refleksivni glagoli (up. Welke 2005: 232).

Medijalno refleksivni su, prema Welkeovoj definiciji, samo oni refleksivni glagoli koji imaju svoj tranzitivni nerefleksivni pandan. Proces nastajanja refleksivnih intranzitivnih glagola od nerefleksivnih tranzitivnih glagola Welke naziva "medijalizacija". Ovi su glagoli u pogledu izraza tranzitivni, a u pogledu značenja intranzitivni, što znači da označavaju stanje medija, tj. srednje stanje, stanje između aktiva i pasiva (Duden 2005: 1107). ${ }^{2}$ Povratna zamjenica sich je kod medijalno refleksivnih glagola u njemačkom jeziku "marker intran-

"Mittelform zwischen Aktiv u. Passiv (bes. im Griechischen), der in anderen Sprachen die reflexive Form entspricht: dieses Verb kommt nur im M. vor" (Stanje glagola između aktiva i pasiva (osobito u grčkom jeziku), kojemu u drugim jezicima odgovara refleksivna upotreba glagola: (...)” (prev. Z. L). 
zitivnosti / neprijelaznosti" (Welke 2005: 248). Mogućnost medijalne upotrebe glagola jednaka je mogućnosti da nešto zamislimo kao proces neovisan o agensu, čime je i ograničena mogućnost tvorbe medijalno refleksivnih glagola. Welke (2005: 244) tipičnim medijalnim glagolima smatra medijalne glagole s neosobnim subjektom:

Jemand öffnet / schloss die Tür. (Neko je otvorio / zatvorio vrata.) (prijelazni glagol) i

$\rightarrow$ Die Tür öfnete / schloss sich geräuschlos. (Vrata su se otvorila / zatvorila nečujno.) (medijalno refleksivni glagol).

Rečenice poput sljedećih nisu moguće bez agensa, te su kao takve negramatične (Welke 1997: 218): ${ }^{\star}$ Der Brief schreibt sich (Pismo se piše), ${ }^{\star}$ Das Gras mäht sich (Trava se kosi), jer ove dvije radnje nije moguće zamisliti kao proces neovisan o agensu.

U upotrebi nalazimo i primjere refleksivizacije intranzitivnih glagola, kojom se povratna zamjenica sich dodaje neprijelaznom / intranzitivnom glagolu po analogiji na tvorbu medijalno refleksivnih glagola (Welke 2005: 232).

\subsection{Kategorija refleksivnosti u bosanskom jeziku}

Kategorija povratnosti u bosanskom jeziku svojstvena je zamjenicama (u obliku upotrebe povratne zamjenice se / sebe i prisvojnopovratne zamjenice svoj) i glagolima koji uza se imaju enklitički oblik povratne zamjenice se (povratni glagoli), kao i glagolima uz koje se se kao morfološka oznaka koristi za izražavanje različitih značenja kao i različitih glagolskih kategorija (reciprocitet, pasiv, bezličnost). Analiza prikaza kategorije povratnosti / refleksivnosti, osobito u domeni glagola, u gramatikama bosanskog jezika ukazuje na potrebu redefiniranja pojedinih pojmova u okviru polja refleksivnosti, te usklađivanja postojećih tumačenja sa savremenim dostignućima u lingvistici.

Lingvističkoj javnosti Bosne i Hercegovine poznate su samo tri gramatike bosanskog jezika i to: Gramatika bosanskog jezika za srednje škole, koja je Nakladom Zemaljske vlade za Bosnu i Herce- 
govinu štampana u Zemaljskoj štampariji u Sarajevu 1890. godine, i dvije gramatike bosanskog jezika objavljene početkom 21. stoljeća: Gramatika bosanskoga jezika (Jahić, Dž. - Halilović, S. - Palić, I. 2000) i Osnovi gramatike bosanskog jezika (Čedić 2006).

Sve tri gramatike bosanskog jezika jedinstvene su u pogledu statusa zamjenice sebe / se u okviru sistema kategorija vrsta riječi, te je smatraju ličnom zamjenicom "za sva tri lica" (GBJ 1890:57) ili ličnom zamjenicom "za svako lice" (Jahić et al. 2000: 245) koja "objedinjava zamjenice za prvo, drugo i treće lice" te se upotrebljava "u slučajevima kad izgleda da se glagolska radnja vraća na ono što joj prethodi, a da se ne bi ponovila riječ u službi subjekta: Pomogao je sebi. Našminkala se da ljepše izgleda." (Čedić 2006: 108). Čedić prisvojne zamjenice definira kao vrstu "upućivačkih riječi koje kazuju kojem govornom licu šta pripada”, npr. $m o j, t v o j$, naš, te u tom smislu i zamjenica sebe, se ima svoj par u prisvojnoj zamjenici svoj (2006: 110).

Povratnost kao glagolsku kategoriju u sve tri gramatike nalazimo opisanu kao jednu od klasa u okviru podjele glagola prema kriteriju prijelaznosti. Prema GBJ (1890: 84) povratni ili refleksivni glagoli su "prijelazni glagoli, kada imaju uza se povratnu ili refleksivnu zamjenicu se i naznačuju, da se djelovanje glagolsko povraća na isti subjekt, koji vrši glagolsku radnju, n. pr. kunem se, pere se, oblačimo se, svlačite se i t. d.. Uz navedeno objašnjenje ova gramatika daje napomenu:

Neki glagoli upotrebljavaju se samo s povratnom zamjenicom se, a bez nje ne znače ništa; stoga se ne zovu povratni već medijalni. Takovi su n. pr. bojim se, čudišse, divimo se, kaju se, stidim se, nadamo se, radujem se, smijem se, znojim se. (GBJ 1890: 84).

GBJ (Jahić et al. 2000: 261) prema kriteriju prijelaznosti razlikuje prijelazne glagole kojima je za realiziranje radnje potreban objekt (npr. čitati knjigu) i neprijelazne glagole čija se radnja ne vrši ni na kakvom predmetu, tj. objektu (npr. šetati). Prema ovim autorima:

neprelazni su i povratni (refleksivni) glagoli - njihova radnja prelazi na objekt, ali je u njih objekt jednak subjektu; radnja se, dakle, vraća na subjekt (ovi su glagoli morfološki obilježeni: uza 


\section{KNJIŽEVNI JEZIK 29, 2018. (139-158]}

se imaju povratnu zamjenicu se, koja se uvijek može zamijeniti punim oblikom sebe): čuvati se, hvaliti se, umivati se, ispraviti se, napiti se, spremiti se. Povratnim su glagolima slični glagoli: hrvati se, igrati se, potući se, takmičiti se i sl., u kojih radnju vrše najmanje dva subjekta (ili više njih) jedan na drugom, te glagoli koji označavaju različita stanja, raspoloženja, procese u prirodi i sl.: brinuti se, čuditi se, ljutiti se, smijati se, vedriti se. Uz njih se riječ se ne može zamijeniti oblikom sebe, jer to i nije povratna zamjenica, nego povratna riječca (Jahić et al. 2000: 262).

OGBJ (Čedić 2006: 119) klasificira glagole prema kriteriju prijelaznosti na prijelazne, neprijelazne i povratne. Povratni ili refleksivni glagoli su prema ovom autoru posebna grupa glagola "kod kojih radnja prelazi na objekat, ali je taj objekat jednak subjektu i prepoznaju se po tome što uza se imaju uvijek povratnu zamjenicu se: češljati se, umivati se, čuvati se itd.” Na osnovu mogućnosti zamjene enklitičkog oblika zamjenice se punim oblikom sebe povratni se glagoli dalje dijele na prave povratne (kod kojih je ta zamjena moguća: Derviša se češlja = Derviša sebe češlja) i neprave povratne (kod kojih ova zamjena nije moguća, a koji uglavnom označavaju unutarnja stanja subjekta: On se puno sekira. Začudio se u tom trenutku. Smijala se cijeli dan.). Kao posebnu grupu povratnih glagola ova gramatika navodi uzajamno ili recipročno povratne, kod kojih radnju vrši uzajamno više subjekata: Žene se svađaju. Djeca su se potukla. (Čedić 2006: 119f)

\section{Korpus i metodologija}

Njemački lingvista Klaus Welke (2005) smatra da su u početnoj fazi razvoja jezika nastajali prvenstveno inherentno refleksivni glagoli po tvorbenim modelima nerefleksivnih glagola. U savremenim rječnicima njemačkog jezika većina ovih glagola je stilski obilježena. Medijalno refleksivni glagoli su novijeg porijekla i rijetko su stilski obilježeni. Refleksivizacija neprijelaznih glagola proces je koji je tek $\mathrm{u}$ začetku, ali je u određenim kontekstima vidljivo da refleksivna zamjenica i kod ovih glagola nijansira ili mijenja značenje. Reflek- 
sivizacija tranzitivnih glagola jedan je od najčešćih načina tvorbe novih intranzitivnih glagola $\mathrm{u}$ funkciji promjene perspektivizacije izvanjezičke stvarnosti premještanjem pogleda s radnje na proces. Cilj ovog rada je dokazati da se isti procesi mogu pratiti i u bosanskom jeziku.

U skladu s ciljem istraživanja za korpus istraživanja odabrana su dva rječnika bosanskog jezika, koji su vremenski "udaljeni” i predstavljaju različite faze razvoja bosanskoga jezika. Rječnik bosanskoga jezika (Isaković 1995) predstavlja uvod u standardizaciju bosanskog jezika i raniju fazu u razvoju leksike bosanskog jezika. Rječnik bosanskog jezika (Čedić et al. 2007) važi za rječnik standardnog bosanskog jezika.

U skladu s kretanjima u savremenoj lingvistici u radu je primijenjena metoda korpusne lingvistike, koja podrazumijeva kombinaciju kvantitativne i kvalitativne metode te omogućava kvalitetan materijal za analizu. Težište je u ovoj fazi istraživanja na kvantitativnoj metodi, kojom se daje uvid $\mathrm{u}$ frekventnost pojedinih klasa refleksivnih glagola. Budući da je u Rječniku bosanskoga jezika Alije Isakovića pronađeno ukupno 295 refleksivnih glagola, ekscerpiran je isti broj refleksivnih glagola i iz Rječnika bosanskog jezika Instituta za jezik u Sarajevu. Izvršena je klasifikacija refleksivnih glagola ekscerpiranih iz svakog rječnika posebno. Materijal je klasificiran uz primjenu modela klasifikacije i terminologije koji je u njemačkoj lingvistici za klasifikaciju i opis refleksivnih glagola ponudio Welke (2005). Analizi su podvrgnuti samo refleksivni glagoli kod kojih je povratna zamjenica se dio glagolskog leksema koji skupa s glagolom predstavlja jedinstvo forme i značenja i leksikonsku jedinicu. Nakon utvrđivanja frekventnosti pojedinih klasa refleksivnih glagola u dva odabrana rječnika bosanskog jezika, koji oslikavaju različite faze razvoja bosanskog jezika, pokušat ćemo na odabranim primjerima ilustrirati leksikalizaciju pojedinih klasa u prvom (još nezavršenom) enciklopedijskom Rječniku bosanskog jezika autora Dževada Jahića (Jahić 2010). 


\section{Pravci razvoja refleksivnih glagola u bosanskom jeziku}

\subsection{Refleksivni glagoli u Rječniku bosanskoga jezika Alije Isakovića (RBJAI)}

Iz kompletnog izdanja rječnika RBJAI ekscerpirano je ukupno 295 leksički refleksivnih glagola, od toga 261 inherentno refleksivnih, 29 medijalno refleksivnih i 5 refleksivizacija neprijelaznih glagola. Ukupno 261 glagol je inherentno refleksivni (IRG), tj. glagol koji nema svoj pandan u nerefleksivnom glagolu. Ovi glagoli nastali su kao refleksivni po tvorbenim modelima po kojima nastaju nerefleksivni glagoli i refleksivnost je inherentno ${ }^{3}$ svojstvo ovih glagola. Analiza tvorbenih modela po kojima nastaju IRG mogla bi biti predmetom posebnog istraživanja, jer su oni raznovrsni i karakteristični za svaki jezik. Iz navedenog popisa IRG uočava se da se ove refleksivne konstrukcije uglavnom pojavljuju s osobnim subjektom. IRG čiji je subjekt osoba označavaju unutarnje ili spoljne procese na čovjeku. Aktivnost izraženu ovom klasom glagola čovjek usmjerava prema sebi, a ne prema drugima. Analiza pokazuje da u RBJAI, koji oslikava raniju fazu u razvoju bosanskog jezika, 261 refleksivni glagol (ili $88,47 \%$ ) je inherentno refleksivan. Uvid u listu IRG ${ }^{4}$ pokazuje

3 Bratoljub Klaić (2004: 589): “inherencija lat. (inhaerere - (...) odnos svojstava prema njihovom nosiocu, nerazdvojnost, bitna pripadnost nečemu; inherentan (...) nerazdvojivo spojen s nečim; (...) svojstven, bitan) (...)".

4 Inherentno refleksivni glagoli u RBJAI (261 / 88,47\%): abdestati se, abdestiti se, ašik se učiniti, avdestiti se, averiti se, avizati se, bahtati se, bakamiti se, baktati se, banjati se, bastati se, baštati se, bebinjati se, bečiti se, behnuti se, benevrečiti se, benevrećiti se, blahnuti se, blanuti se, bohrati se, borhati se, čahuriti se, čiftati se, čiftekati se, čiftnuti se, ćiftnuti se, ćufuriti se, derlučiti se, džilitati se, džilitnuti se, džombosati se, gornjati se, grstiti se, grudati se, haberisati se, harati se, harumiti se, haruniti se, hazuriti se, hihotati se, hiljaditi se, hohotati se, horiti se, hrnjati se, hrnjegati se, hrvati se, rvati se, hvalisati se, hvastati se, hvatiti se, inaditi se, inpačati se, ispričavati se, iščahuriti se, iščuriti se, išuljati se, iženiti se, jabukat se, japuriti se, jevrcati se, jezeriti se, kesiti se, kikotati se, kiniti se, klamišiti se, knjigati se, kobacati se, kojasiti se, kopuniti se, kostrešiti se i kostriješiti se, kovrljati (se), kozati se, ljenkati se, mahnuti se, manuti se, maskariti se, mašiti se, mladunjati se, mraziti se, muhati se, muvati se, naašikovati se, načečiti se, 
također da ovi glagoli, upotrijebljeni u savremenom jeziku, uglavnom nose određene negativne konotacije (npr. averiti se, bebinjati se, čiftekati se itd.) te bi u rječniku savremenog bosanskog jezika morali biti stilski obilježeni.

Medijalno refleksivni glagoli nastaju procesom refleksivizacije (medijalizacije) primarno nerefleksivnih prijelaznih glagola po shemi [glagol $+s e$ ]. Forma osnovnog glagola ostaje nepromijenjena, ali se otvara mogućnost da se njegovo značenje, zahvaljujući procesima metaforizacije, shvati šire i apstraktnije te da mu se u novoj konstelaciji aktanata pridruže nova značenja. U rječnicima se se uz ove glagole stavlja u zagradu, što ukazuje na postojanje nerefleksivne varijante, npr. izdati (se). U RBJAI registrirano je ukupno $29 \mathrm{MRG}^{5}$ ili 9,83\% od ukupnog broja leksički refleksivnih glagola.

$\mathrm{U}$ istom se rječniku pojavilo ukupno 5 ili $1,70 \%$ refleksivizacija neprelaznih glagola. ${ }^{6}$ Registriranje navedenih triju klasa refleksivnih glagola u RBJAI potvrđuje da se i u bosanskom jeziku mogu pratiti isti procesi refleksivizacije kakvi su uočeni u njemačkom jeziku.

naćosati se, nahakaretiti se, nahaljetati se, nahlipiti se, nahoditi se, nahoroziti se, najaditi se, nakrhati se, nasmjehivati se, nasrhnuti se, nastrhnuti se, nasuliti se, natjecati se, natkučiti se, neosvistit (se), nihnuti se, njeprcati se, njihnuti se, obazreti se, obazrijeti se, obiknuti se, obligati se, obneviriti se, očitovati se, odhrvati se, odrvati se, odvaljutnuti se, oglušiti se, ohalasiti se, ohavizati se, ohljebiti se, okladiti se, okojasiti se, ominjati se, onesvijestiti se, opendžiti se, oriti se, osanisati se, osmihnut se, osmjehnuti se, osupnuti se, ošvanjiti se, otabati se, othrvati se, odrvati se, otkameniti se, ovataniti se, ovizati se, ozlosrdit se, pačati se.

5 Medijalno refleksivni glagoli u RBJAI (29/9,83\%): izbirikati (se), iznevjeriti (se), izdati (se), kratiti (se), pofalit (se), pograđančiti (se), poharati (se), pohvalit (se), pohvaliti (se), pokloniti (se), pokoravati (se), ponjegoviti (se), prepasti (se), preporučati (se), preporučavati (se), prevariti (se), priključiti (se), primaknuti (se), rashodžiti (se), rasrditi (se), razljutiti (se), ražljutiti (se), ulijevati (se), umirnodobiti (se), urahatiti (se), uzbihuzuriti (se), zadijevati (se), zadivati (se), zagušiti (se).

6 Refleksivizacija neprijelaznih glagola u RBJAI (5 / 1,70\%): đuskati (se), ličiti (se), vihoriti (se), vijoriti (se), virnuti (se), ličiti (se). 


\title{
KNJIŽEVNI JEZIK 29, 2018. (139-158]
}

\subsection{Refleksivni glagoli u Rječniku bosanskog jezika Ibrahima Čedića et al.}

\author{
Iz RBJIČ ekscerpiran je isti broj refleksivnih glagola u svrhu lakšeg \\ poređenja rezultata istraživanja. Glagoli su ekscerpirani po redosli- \\ jedu kako su registrirani u Rječniku. U RBJIČ, koji važi kao rječnik \\ standardnog bosanskog jezika, od ukupno 295 analiziranih leksički \\ refleksivnih glagola pronađen je $121(41,02 \%)$ inherentno refleksivni \\ glagol $^{7}$ te $154(52,20 \%)$ medijalno refleksivna glagola ${ }^{8}$ i $20(6,78 \%)$
}

Inherentno refleksivni glagoli u RBJIČ (121 / 41,02\%): bacakati se, bailisati se / bajilisati se, baškariti se, batrgati se, baviti se, bližiti se, bočiti se, borati se, boriti se, bratiti se, bratimiti se, busati se, cakliti se, cerekati se, ceriti se, cjenkati se, čiftati se, dernjati se, desiti se, diviti se, dočepati se, dodvoravati se, dodvoriti se, događati se, dogovoriti se, dokotrljati se, domišljati se, domunđavati se, dopasti se, doseljavati se, dosjetiti se, došuljati se, dovijati se, drznuti se, duriti se, dvoumiti se, džapati se, džilitati se, emancipirati se / emancipovati se, gaditi se, geguckati se, glupirati se, gnijezditi se, gnjeviti se, goropaditi se, grbiti se, groziti se, grudati se, grudvati se, grupašiti se, grušati se, guriti se, gušati se, hakaretiti se, hihotati se, hiljaditi se, hvalisati se, hvastati se, ibretiti se, inaditi / inatiti se, inhalirati se, isceriti se, ishodati se, iskilaviti se, iskobeljati se, iskoprcati se, iskradati se, iskrasti se, iskucati se, iskupati se, ispatiti se, ispavati se, ispečiti se, ispeti se, iskakati se, ispopriječiti se, ispotiti se, ispozdravljati se, isprsiti se, iskilaviti se, istutnjati / istutnjiti se, iščahuriti se, iščuditi se, iščuđavati se, izanđati se, izbalegati se, izbečiti se, izborati se, izjadati se, izjaditi se, izjasniti se, izlagati se, izležavati se, izmetnuti se, izmigoljiti se, izmotavati se, izobraziti se, izraditi se, izubijati se, izviniti se, izvitoperiti se, izvještiti se, jadati se, jaloviti se, janjiti se, jediti (se), ježiti se, jotovati se, junačiti se, kajati se, kaniti se, kaskatiti se, kesiti (se), kilaviti se, kladiti se, klanjati se, kloniti se, kobeljati se, kostriješiti se, kretati se, kurisati se.

8 Medijalno refleksivni glagoli u RBJIČ (154 / 52,20\%): adaptirati (se), afirmisati / afirmirati (se), aktivirati (se), angažirati / angažovati (se), baciti se, bijeliti - bijeljeti se, blamirati (se), brčkati (se), brčnuti (se), buniti (se), cifrati se, cijeniti (se), činiti se, čistiti se, demoralisati / demoralizirati (se), derati se, distancirati (se), dodirivati (se), dopisivati (se), doseliti (se), doškolovati (se), dotaknuti (se), držati - držati se, đorati (se), eksponirati (se), frustrirati (se), gasiti (se), glodati (se), gojiti (se), goniti (se), ganjati (se), gostiti (se), granati (se), grebati (se), grijati (se), gristi (se), grliti (se), grogirati (se), grohotati (se), grupisati (se), gubiti (se), gurati (se), gusuliti (se), gušiti (se), gužvati (se), halaliti (se), hladiti (se), hraniti (se), hvaliti (se), hvatati (se), identificirati / identifikovati (se), igrati (se), informirati / informisati (se), interesirati / interesovati (se), iscrpiti (se), iseliti (se), iseljavati (se), iskakati (se), iskaliti (se), iskazati (se), iskesiti (se), iskidati (se), iskositi (se), iskrcati (se), iskrcavati (se), iskričiti (se), iskriviti (se), iskrviti (se), iskrzati (se), iskupiti (se), iskušati (se), iskvariti (se), ismijati (se), ismijavati (se), ispeći (se), ispeljati (se), ispiliti (se), ispjevati (se), isplakati (se), ispostaviti (se), ispotpisivati (se), ispovijediti se, ispovraćati (se), ispraskati se, isprati (se), isprebijati (se), ispriječiti (se), ispružiti (se), ispržiti (se), ispucati (se), ispuhati (se), istaknuti (se), iskaliti (se), iskesiti (se), iskidati 
refleksivizacija neprijelaznih glagola. ${ }^{9}$ Udio pojedinih klasa analiziranih refleksivnih glagola u istraženim rječnicima znatno se razlikuje. Evidentno je da je proces nastajanja refleksivnih glagola kontinuiran. Rezultati istraživanja pokazuju da je u rječniku standardnog bosanskog jeziku RBJIČ manji broj inherentno refleksivnih glagola, dok je broj medijalno refleksivnih glagola, nastalih refleksivizacijom postojećih prijelaznih glagola, znatno veći u odnosu na RBJAI. Uočen je i znatan porast refleksivizacije neprijelaznih glagola.

\subsection{Leksikalizacija refleksivnih glagola u RBJDJ}

Pod pojmom "leksikalizacija" Bußman (2008: 404) podrazumijeva uključivanje jezičkih struktura sa sinhronijskog aspekta u leksiku određenog jezika, čime im se dodjeljuje status konvencionaliziranih leksičkih jedinica, pohranjenih u leksikonu i spremnih za upotrebu. ${ }^{10}$ $\mathrm{Na}$ odabranim jednostavnim primjerima natuknica leksički refleksivnih glagola iz Rječnika bosanskog jezika autora Dževada Jahića (RBJDJ) posmatrat ćemo kako su procesi refleksivizacije registrirani u ovom Rječniku, koji je i prvi enciklopedijski rječnik bosanskog jezika, te kao takav pruža mogućnost za kompleksniju analizu razvoja određenih jezičkih jedinica. Smatramo, međutim, da bi obimnije istraživanje članaka uz refleksivne glagole kao natuknice u

(se), istrenirati (se), istresti (se), istrgnuti (se), istrošiti (se), istuširati (se), iščupati (se), išetati (se), izbezumiti (se), izbistriti (se), izbljuvati (se), izdavati (se), izderati (se), izdići (se), izdignuti (se), izduljiti (se), izdužiti (se), izdvojiti (se), izgubiti (se), izigrati (se), izjedati (se), izjednačiti (se), izlagati (se), izlagati (se), izleći (se), izljubiti (se), izmijeniti (se), izmrcvariti (se), izmučiti (se), iznenaditi (se), iznenađivati (se), iznervirati (se), izobličiti (se), izranjavati (se), izranjaviti (se), izroditi (se), izuti se, izvagati (se), izvaliti (se), izvikati (se), izviti (se), izvlačiti (se), izvozati (se), izvrnuti (se), iživljavati (se), javiti (se), kaliti (se), kandidirati / kandidovati (se), karati (se), kinđuriti (se), kleti (se), kljukati (se), kočiti (se), koncentrirati / koncentrisati (se), kondenzirati / kondenzovati (se), konfrontirati (se), konsolidirati / konsolidovati (se), kotrljati (se), kovrdžati (se), kriti (se).

9 Refleksivizacija neprijelaznih glagola u RBJIČ (20 / 6,78\%): blistati (se), bljeskati (se), bogatiti (se), brecati (se), brecnuti (se), crnjeti (se), crvenjeti (se), dogegati se, doklatariti se, glasati - glasati se, isparavati (se), ispariti se, išetati (se), izeglenisati (se), izjaloviti (se), iznojiti (se), jarcati (se), jutriti (se), kartati (se), kockati (se).

10 "Lexikalisierung. 1. Unter synchronem Aspekt Aufnahme in den Bestand der Sprache als usuelle Bildung, die im Lexikon gespeichert und bei Gebrauch dort abgerufen wird. (...)" 


\section{KNJIŽEVNI JEZIK 29, 2018. (139-158]}

ovom rječniku rezultiralo vrlo korisnim informacijama o nastajanju novih refleksivnih glagola u svrhu izražavanja novih značenja, što se svakako preporučuje kao tema za dalja istraživanja kategorije refleksivnosti u bosanskom jeziku.

Inherentno refleksivni glagoli su u svom prvom pojavljivanju refleksivni glagoli i u rječniku imaju registriranu samo refleksivnu varijantu. Povratno se kod ovih je glagola sastavni dio leksikonske natuknice, što pokazuje i leksikonski unos glagola desiti se u enciklopedijskom Rječniku bosanskog jezika Dževada Jahića (2010):

desiti se - svrš. prema nesvrš. dešavati se < prez. desi $(m)$ se [...]

1. dogoditi se, zbiti se [desilo se to iznenada] i

2. etnol. naći se, trefiti se na nekome mjestu, zateći se.

Jednostavan primjer medijalizacije u smislu postojanja tranzitivne / nerefleksivne varijante i intranzitivne / refleksivne varijante možemo posmatrati kod glagola distancirati - distancirati se. Jahić bilježi kao prvu varijantu ovog glagola - nerefleksivnu varijantu s konkretnim značenjem: distancirati nekoga, nešto (1) u značenju "nekoga, nešto udaljiti", a kao drugu varijantu - refleksivnu varijantu konkretnog značenja distancirati se / sebe (2. a) "udaljiti se od nekoga ili nečega". U trećoj varijanti (2. b) refleksivnom glagolu pridruženo je apstraktno značenje "ograditi se od nečijeg mišljenja, od nečijeg stava i djelovanja”. Glagol distancirati (se) ima, dakle, nerefleksivni tranzitivni pandan distancirati nekoga, nešto i dvije refleksivne varijante, i to jednu s konkretnim i jednu s apstraktnim značenjem. Prema Welkeovoj definiciji medijalizacije ovaj glagol je medijalno refleksivni, a kod nastajanja novog značenja jasno je uočljiv pravac od konkretnog prema apstraktnom značenju, što možemo pratiti u Jahićevom rječniku (2010):

distancirati (nekoga, nešto)

1. nekoga, nešto udaljiti $\mathrm{i}$

2. (se) (od nekoga ili nečega), 
a) udaljiti se od nekoga ili nečega (od ljudi, od društva),

b) ograditi se od nečijeg mišljenja, od nečijeg stava ili djelovanja.

I kod refleksivizacije neprijelaznih glagola uočljiv je pravac promjene značenja od konkretnog prema apstraktnom, što ilustrira i primjer glagola blistati / blistati se. Navode o refleksivnoj i nerefleksivnoj upotrebi glagola Jahić predstavlja u zagradi (ø, se), pri čemu znak zero među zagradama (ø) u Jahićevom rječniku "iza glagolskog oblika označava neprelaznost (...)” (up. Jahić 2010):

blistati (ø, se) nesvrš. < prez. blistam (se) [...]

1. (se) jako, jarko sijati, odavati svjetlost bliještanjem [...];

2. pren. pokazati sjajne rezultate, ostaviti izuzetan dojam, isticati se izuzetnim osobinama;

$\times$ blistati od sreće - biti izuzetno zadovoljan, sretan zbog nečega.

\section{Zaključno o tendencijama refleksivizacije u bosanskom jeziku}

Istraživanje odabranih rječnika bosanskog jezika potvrdilo je da je u bosanskom jeziku nastajanje novih refleksivnih glagola kontinuiran proces. I u bosanskom jeziku prisutni su modeli nastajanja refleksivnih glagola uočeni u njemačkoj lingvistici. Analiza refleksivnih glagola u odabranim rječnicima bosanskog jezika koji predstavljaju različite faze u razvoju bosanskog jezika pokazuje da su trendovi prisutni u nastajanju novih refleksivnih glagola u bosanskom jeziku identični s procesima koji se odvijaju u njemačkom jeziku. U ranijoj fazi razvoja jezika i u bosanskom jeziku nastajali su uglavnom inherentno refleksivni glagoli. I u bosanskom jeziku su medijalno refleksivni glagoli novijeg porijekla i njihov broj je u odnosu na predstandardizacijski period znatno povećan. I refleksivizacija neprijelaznih glagola je proces novijeg porijekla i takve tendencije mogle bi biti opisane tek kroz obimna korpusna istraživanja. Uočljivo je, među- 


\section{KNJIŽEVNI JEZIK 29, 2018. (139-158]}

tim, da se i kod ovih glagola zamjenica se ne može smatrati fakultativnom. I kod ove grupe glagola prisustvo povratne zamjenice se uvijek znači nijansiranje ili veću ili manju promjenu značenja. Cilj ovog rada je i da potakne nova istraživanja na polju refleksivnosti, kao i kontrastivna istraživanja drugih jezičkih struktura bosanskog i drugih jezika.

\section{Literatura}

Buscha, Joachim (1982): "Reflexive Formen, reflexive Konstruktionen und reflexive Verben", Deutsch als Fremdsprache 19, 167-174.

Bußmann, Hadumod (2002): Lexikon der Sprachwissenschaft, Alfred Kröner Verlag, Stuttgart.

Čedić, Ibrahim (2006): Osnovi gramatike bosanskog jezika, Institut za jezik, Sarajevo.

Čedić, Ibrahim et al. (2007): Rječnik bosanskog jezika, Institut za jezik, Sarajevo.

Duden Band 4 (2006): Die Grammatik. Herausgegeben von der Dudenredaktion. 7., völlig neu erarbeitete und erweiterte Auflage, Dudenverlag, Mannheim / Leipzig / Wien / Zürich.

Duden (2005): Deutsch-kroatisches Universalwörterbuch, Globus, Zagreb.

Fischer, Kerstin, Stefanowitsch, Anatol (ur.) (2008): Konstruktionsgrammatik: Von der Anwendung zur Theorie, Stauffenburg, Tübingen.

Helbig, Gerhard, Buscha, Joachim (1998): Deutsche Grammatik. Ein Handbuch für den Ausländerunterricht, Langenscheidt, Berlin / München / Wien / Zürich / New York.

Helbig, Gerhard, Buscha, Joachim (2001): Deutsche Grammatik. Ein Handbuch für den Ausländerunterricht, Langenscheidt, Berlin / München / Wien / Zürich / New York.

Helbig, Gerhard (2004): Zum "Reflexivpassiv uns zum 'Medio-Passiv' im Deutschen", Deutsch als Fremdsprache 1, 19-27. 
Hundt, Markus (2002): "Formen und Funktionen des Reflexivpasivs im Deutschen", Deutsche Sprache 30 (2/02), Erich Schmidt Verlag, 124-166.

Isaković, Alija (1995): Rječnik bosanskoga jezika, Bosanska knjiga, Sarajevo.

Jahić, Dževad, Halilović, Senahid, Palić, Ismail (2000): Gramatika bosanskoga jezika, Dom Štampe, Zenica.

Jahić, Dževad (2010): Rječnik bosanskog jezika, Bošnjačka asocijacija, Sarajevo.

Klaić, Bratoljub (2004): Rječnik stranih riječi, Nakladni zavod MH, Zagreb.

Lagumdžija, Zineta (2018): Kategorija refleksivnosti u političkom izvještavanju njemačkih dnevnih novina, Univerzitet u Bihaću, Pedagoški fakultet, Bihać.

Naklada Zemaljske vlade za Bosnu i Hercegovinu, Sarajevo (1890): Gramatika bosanskog jezika za srednje škole, Bosanska riječ - Das bosnische Wort, Wuppertal - Tuzla.

Riđanović, Midhat (2003): Totalni promašaj. Prikaz Gramatike bosanskoga jezika Dž. Jahića, S. Halilovića, I. Palića, "Šahinpašić", Sarajevo.

Welke, Klaus (1997): "Eine funktionalgrammatische Betrachtung zum Reflexivum: das Reflexivum als Metapher", Deutsche Sprache 25 (3/97), Erich Schmidt Verlag, 209-231.

Welke, Klaus (2005): Deutsche Syntax Funktional. Perspektiviertheit syntaktischer Strukturen, Stauffenburg, Tübingen. 


\section{REFLEXIVE VERBS AND THEIR \\ LEXICALIZATION IN SELECTED DICTIONARIES OF BOSNIAN LANGUAGE}

Abstract: In parallel with the changes in extralingual reality new means of communication are being developed. In language, as a means of communication, occur new linguistic structures and new description models of language structures. One of the linguistic phenomenon that has experienced a great interest in the German linguistics are reflexive verbs, whose formation has proved to be an open process and a reflection of the creative use of language. Insight into the different text types and dictionaries of Bosnian language shows that the reflexive verbs are very common in the Bosnian language. In the Bosnian linguistics these structures haven't encountered on the interest they deserve. As seen in the example of reflexive verbs, it is showed that trends in the development of linguistics in developed linguistic systems are often due to language barriers with considerable delay due to, so to speak, less developed language systems. The goal of this paper is to give an overview on the processes of formation of reflexive verbs and their lexicalization in selected dictionaries of Bosnian language using one of the description models of reflexive verbs in German linguistics.

Key words: reflexive verbs, reflexivization, dictionaries of Bosnian language.

Izjava autora o nepostojanju sukoba interesa i poštivanju općih etičkih kodeksa: Autorice potvrđuju da ne postoji nikakav stvarni ili mogući sukob interesa vezan za ovaj tekst te da je tekst napisan u skladu s etičkim kodeksima prema preporukama COPE (Comittee of Publishing Ethics). 